\title{
Review
}

\section{Emerging novel concept of chaperone therapies for protein misfolding diseases}

\author{
By Yoshiyuki SuzukI ${ }^{* 1, \dagger}$ \\ (Communicated by Kunihiko SuzukI, M.J.A.)
}

\begin{abstract}
Chaperone therapy is a newly developed molecular therapeutic approach to protein misfolding diseases. Among them we found unstable mutant enzyme proteins in a few lysosomal diseases, resulting in rapid intracellular degradation and loss of function. Active-site binding low molecular competitive inhibitors (chemical chaperones) paradoxically stabilized and enhanced the enzyme activity in somatic cells by correction of the misfolding of enzyme protein. They reached the brain through the blood-brain barrier after oral administration, and corrected pathophysiology of the disease. In addition to these inhibitory chaperones, non-competitive chaperones without inhibitory bioactivity are being developed. Furthermore molecular chaperone therapy utilizing the heat shock protein and other chaperone proteins induced by small molecules has been experimentally tried to handle abnormally accumulated proteins as a new approach particularly to neurodegenerative diseases. These three types of chaperones are promising candidates for various types of diseases, genetic or non-genetic, and neurological or nonneurological, in addition to lysosomal diseases.
\end{abstract}

Keywords: chaperone therapy, inhibitory chaperone, non-inhibitory chaperone, molecular chaperone, protein misfolding, lysosomal disease

\section{Introduction}

At present more than 7000 inherited diseases are listed in Online Mendelian Inheritance in Man. ${ }^{1)}$ They are mostly caused by single gene mutations, resulting in amino acid substitutions, structural alterations (protein misfolding) and functional defects due to rapid molecular turnover by the endoplasmic reticulum associated degradation system, even if they maintain the functional potential. ${ }^{2)}$ Many of the functional proteins are enzymes and their defects (enzyme deficiency) cause diverse metabolic derangements in human somatic cells.

\footnotetext{
*1 Special Visiting Scientist, Tokyo Metropolitan Institute of Medical Science, Tokyo, Japan.

$\dagger$ Correspondence should be addressed: Y. Suzuki, 1-27-10 Kakinokizaka, Meguro-ku, Tokyo 152-0022, Japan (e-mail: suzuki.y@attglobal.net).

Abbreviations: CFTR: cystic fibrosis transmembrane regulator; DGJ: 1-deoxygalactonojirimycin; ER: endoplasmic reticulum; ERT: enzyme replacement therapy; Hsp: heat shock protein; HGMD: Human Gene Mutation Database; NAC: $N$ acetylcysteine; NOEV: $N$-octyl-4-epi- $\beta$-valienamine; polyQ: polyglutamine.
}

The metabolic defect is expressed generally in various tissues and organs, but most prominently in the central nervous system as neurogenetic diseases in the majority of metabolic diseases.

Protein misfolding has become an important issue for possible molecular therapy in human diseases, as structural corrections by molecular engineering would restore the function of the protein in question, and metabolic abnormalities could be normalized. ${ }^{3)-7)}$ The diseases involving the lysosome, one of the important cellular organelles, have been our major target of research in this direction for the past 20 years. In the lysosome, various high molecular endogenous or exogenous compounds are digested under the acidic condition. The functional defect of somatic cells causes well recognized genetic disease, affecting mainly infants and young children, and rarely in adults. Cellular dysfunction caused by an excessive storage of substrates in the lysosome ensues in humans and other animals with neurological and general somatic manifestations. ${ }^{8)}$ Severity of enzyme deficiency is variable in individual patients. In general, severe enzyme deficiency tends 
Table 1. Effect of protease inhibitors on endogenous or exogenous $\beta$-galactosidase in human fibroblasts

\begin{tabular}{|c|c|c|c|}
\hline Inhibitor & Protease & $\begin{array}{c}\beta \text {-Galactosidase } \\
\text { (endogenous) }^{*}\end{array}$ & $\begin{array}{c}\beta \text {-Galactosidase } \\
\text { (exogenous) }^{* *}\end{array}$ \\
\hline None & & 100 & 100 \\
\hline E-64 & Thiol (Cysteine) $)^{* * *}$ & 430 & 229 \\
\hline Leupeptin & Thiol (Cysteine)*** & 460 & 222 \\
\hline Antipain & Thiol (Cysteine)*** & 490 & 224 \\
\hline Chymostatin & Thiol (Cysteine)*** & 520 & 188 \\
\hline Elastatinal & Elastase & 60 & 103 \\
\hline Pepstatin & Pepsin & 100 & 97 \\
\hline Phosphoramidon & Metallopeptidase & 110 & 88 \\
\hline Bestatin & Aminopeptidase & 110 & 90 \\
\hline
\end{tabular}

*Relative enzyme activity in human fibroblasts with cathepsin A deficiency (galactosialidosis).

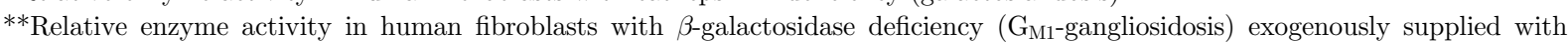
Aspergillus oryzae $\beta$-galactosidase.

***Thiol (cysteine) proteases $=$ Cathepsin B, H, L. Modified from refs. 17 and 18.

to cause development of clinical manifestations in early life.

Since mid-1960s, attempts have been made to treat patients with lysosomal diseases. Enzyme replacement therapy (ERT) has been the most successful approach by intravenous administration of the functional human recombinant enzyme. First, purified $\beta$-glucosidase was shown to be effective for Gaucher disease, the most prevalent lysosomal storage disorder in humans. ${ }^{9)}$ This approach has been extended to other lysosomal diseases, including Fabry disease, mucopolysaccharidoses, and Pompe disease. ${ }^{10)}$ However, the effect has not been confirmed on brain pathology in patients with neurological manifestations. In recent years, however, trials to deliver the enzyme protein to the central nervous system have been made by intrathecal administration of the enzyme in pre-clinical and clinical studies of metachromatic leukodystrophy, ${ }^{11)}$ mucopolysaccharidosis type $1,{ }^{12-14)}$ type $2{ }^{15)}$ and type $6{ }^{16)}$

\section{Turnover of mutant enzyme protein and correlation with the age of onset}

In early 1980s we found that thiol (cysteine) protease inhibitors protected degradation of endogenous human or exogenous fungal $\beta$-galactosidase, ${ }^{17), 18)}$ an enzyme responsible for $\mathrm{G}_{\mathrm{M} 1}$-gangliosidosis in humans (Table 1 ). These results prompted us to search for a new molecular therapy of enzyme deficiency disorders in order to rescue apparently inactive mutant enzyme proteins.

In this connection we found a correlation between residual $\beta$-galactosidase activity and clinical onset in $\mathrm{G}_{\mathrm{M} 1}$-gangliosidosis patients (Fig. 1). ${ }^{19)}$

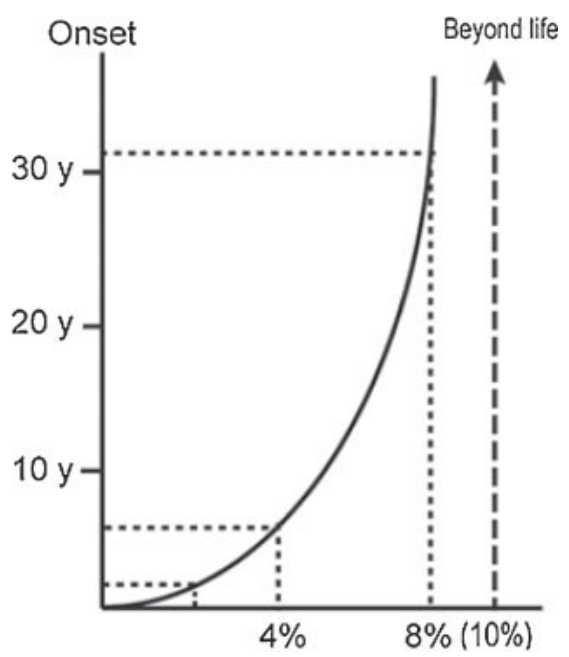

Fig. 1. Correlation between residual $\beta$-galactosidase activity and clinical onset. The amount of residual enzyme activity shows positive correlation with the age of onset in various phenotypic forms of $\beta$-galactosidase deficiency disorders. Theoretically at least $10 \%$ of normal enzyme activity is necessary for washout of the storage substrate. The age of onset in patients expressing enzyme activity above this level will be beyond the human life span. See the text for more details. Reproduced from ref. 19 with minor modifications.

Essentially the same data with theoretical calculations had been reported for some other lysosomal diseases. ${ }^{20)}$

In our data the amount of residual enzyme activity showed positive parabolic correlation with the age of onset in various phenotypic forms of $\beta$ galactosidase deficiency disorders. The enzyme activity was generally less than $3 \%$ of the control mean 


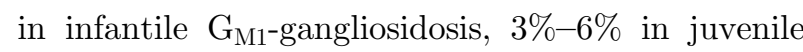
$\mathrm{G}_{\mathrm{M} 1}$-gangliosidosis, and more than $6 \%$ in late onset (adult/chronic) $\mathrm{G}_{\mathrm{M} 1}$-gangliosidosis patients. In addition, Morquio $\mathrm{B}$ disease, another non-neurological phenotype of $\beta$-galactosidase deficiency, showed relatively high residual enzyme activity. Based on these observations, we anticipated that at least $10 \%$ of normal enzyme activity is necessary for washout of the storage substrate in somatic cells, particularly in neuronal cells. The age of onset in patients expressing the enzyme activity above this level will be theoretically beyond the human life span. However, we should keep in mind that this theoretical curve was drawn on the basis of enzyme assay results using cultured skin fibroblasts (not neuronal cells) and a synthetic fluorogenic substrate 4-methylumbelliferyl $\beta$-galactopyranoside (not natural substrates like ganglioside $\mathrm{G}_{\mathrm{M} 1}$ or keratan sulfate). In this calculation, for technical reasons, substrate specificity was not taken into account, although mutant enzymes show different spectra in $\mathrm{G}_{\mathrm{M} 1}$-gangliosidosis and Morquio B disease. ${ }^{21)}$

\section{Theoretical background of chaperone therapy}

In the last decade of the 20th century we found that some mutant $\alpha$-galactosidase A proteins were unstable and unable to express catalytic activities in somatic cells from Fabry patients. ${ }^{22)}$ Galactose and a galactose analogue compound 1-deoxygalactonojirimycin (DGJ) were effective as chaperones to restore the mutant $\alpha$-galactosidase A activity in Fabry cells and tissues. ${ }^{23), 24)}$ Furthermore another galactose analogue $N$-octyl-4-epi- $\beta$-valienamine (NOEV) was found to be effective to restore the mutant $\beta$ galactosidase activity in $\mathrm{G}_{\mathrm{M} 1}$-gangliosidosis cells and tissues. ${ }^{25)}$

Molecular pathology of inherited metabolic diseases can be generally classified into the following three major conditions related to the structure and function of mutant proteins. ${ }^{26)}$

(a) Biosynthetic defect of the protein in question. Mutant enzyme is not synthesized, and accordingly rescue of the protein is not possible.

(b) Defect of biological activity.

In spite of normal biosynthesis, the protein does not maintain biological activity because of its drastic structural abnormality. There is no possibility to restore the biological activity of this molecule.

(c) Unstable mutant protein with normal or nearnormal biological activity.

The mutant protein has normal biological function in its mature form under normal folding. However, it is unstable because of misfolding, and rapidly degraded or aggregated immediately after biosynthesis.

In the third case, the protein function is expected to be restored if the molecule is somehow stabilized and transported to the cellular compartment where it is expected to exhibit biological activity; the lysosome in the case of lysosomal enzyme.

A substrate analogue inhibitor binds to a mutant lysosomal misfolding protein as a kind of chaperone (chemical chaperone), to induce normal molecular folding at the endoplasmic reticulum (ER)/Golgi compartment in somatic cells, resulting in formation of a stable molecular complex at neutral $\mathrm{pH}$. The chaperone compound itself, however, does not refold the target protein, but induces the equilibrium toward the natural correct folding after binding to the active site of wild-type or mutant protein. The protein-chaperone complex is safely transported to the lysosome, where it dissociates under the acidic condition, the mutant enzyme remains stabilized in its normal folding structure, and its catalytic function is expressed (Fig. 2). These molecular events have been partially clarified by analytical and morphological analyses, and computer-assisted prediction of molecular interactions. ${ }^{19), 27)}$ This approach is particularly important for correction of brain pathology if they are delivered to the central nervous system through the bloodbrain barrier. ${ }^{19), 26)}$ Chaperone therapy is theoretically effective in $30-60 \%$ of patients with Fabry disease and $\mathrm{G}_{\mathrm{M} 1}$-gangliosidosis patients. ${ }^{28), 29)}$

This is the principle of chaperone therapy to restore the enzyme activity by low molecule inhibitors (chaperones) with appropriate molecular structure fitting in the enzyme molecule. A similar concept was presented for cystic fibrosis and other diseases. ${ }^{3), 30)}$

Chaperon (without e) was imported from the French language, and appeared in the English literature in 1380 , meaning a hood or cap worn by nobles. ${ }^{31)}$ The word usage gradually changed over time, and started meaning an elderly woman accompanying a young unmarried lady in public as guide and protector (1720). ${ }^{31)}$ For this reason, chaperone (with e) is often used as a feminine word at present, and also in this article. Then molecular chaperone appeared as an endogenous protein for proper folding and/or assembly of another protein or protein complex, ${ }^{32}$ followed by chemical chaperone ${ }^{33)}$ and chaperone therapy. ${ }^{34), 35)}$ At present chemical or pharmacological chaperone is used as a low molecular compound that stabilizes mutant protein and induces 


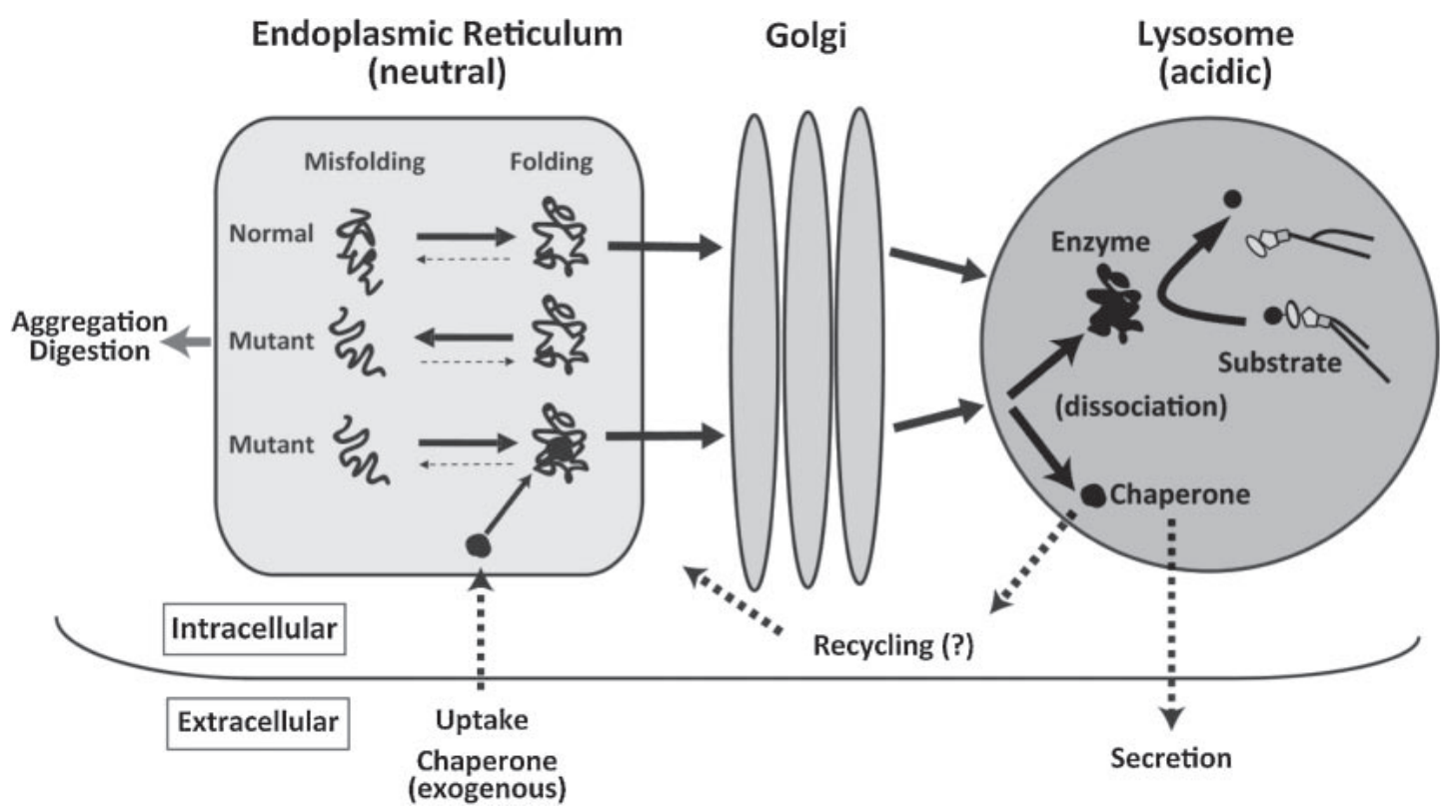

Fig. 2. Postulated molecular events between mutant enzyme molecules and chaperone compounds. Mutant enzyme protein is unstable in the ER-Golgi compartment at neutral $\mathrm{pH}$, and rapidly degraded or aggregated possibly to cause ER stress. An appropriate substrate analogue inhibitor binds to misfolded mutant protein as chaperone at the ER-Golgi compartment in somatic cells, resulting in normal folding and formation of a stable complex at neutral $\mathrm{pH}$. The protein-chaperone complex is safely transported to the lysosome. The complex is dissociated under the acidic condition and in the presence of excessive storage of the substrate. The mutant enzyme remains stabilized, and express catalytic function. The released chaperone is either secreted from the cell or recycled to interact with another mutant protein molecule. Reproduced from ref. 19 with minor modifications.

expression of its biological activity in the cell, by accelerating correct folding of the relevant protein molecule.

\section{Chaperone therapy for lysosomal diseases}

$\alpha$-Galactosidase A deficiency (Fabry disease). Fabry disease is an inherited generalized vasculopathy caused by $\alpha$-galactosidase A gene mutations, resulting in enzyme deficiency and an increasing storage of globotriaosylceramide in the vascular endothelium. Clinically the patients present with acroparesthesia, ankiokeratoma and hypohydrosis of the skin in the early stage of the disease, and progressive involvement of the brain, heart, and kidneys after middle ages. More than 500 gene mutations coding for the enzyme have been recorded in Fabry patients in the Human Gene Mutation Database (HGMD). ${ }^{36)}$ In this disease the p.Q279E mutant enzyme was low in catalytic activity, and unstable at relatively high temperature and also at neutral $\mathrm{pH}^{22)}$ It was rapidly degraded because of molecular misfolding. A high dose of galactose in the culture medium induced a high expression of catalytic activity in Fabry lymphoblasts and mutant enzyme-expressing COS-1 cells. ${ }^{23)}$ However, we thought that galactose was practically not an ideal candidate for restoration of the mutant enzyme in human tissues, as it is rapidly metabolized in cells and tissues, and the continuously high galactose concentration in somatic cells could cause direct galactose intoxication such as galactosemia, and result in pathological osmolarity in the extracellular fluid higher than that in the human blood under the physiological condition, causing significant dehydration, shrinkage and dysfunction of somatic cells. A long-term treatment with galactose at such a high dose would not be realistic, although a human experiment of intravenous galactose infusion every other day for 2 years was reported, achieving a beneficial effect on hypertrophic cardiomyopathy in a Fabry patient. ${ }^{37)}$ DGJ showed the chaperone effect specifically on mutant $\alpha$-galactosidase A. Its chaperone activity toward mutant $\beta$-galactosidase was 50 fold lower in a culture system experiment. ${ }^{38)}$ The phase 3 clinical study is currently in progress.

$\boldsymbol{\beta}$-Galactosidase deficiency ( $\mathrm{G}_{\mathrm{M} 1}$-gagliosidosis and Morquio B disease). $\mathrm{G}_{\mathrm{M} 1}$-gagliosidosis is a relatively rare lysosomal disease, presenting clinically with progressive neurological deterioration mainly in infancy and childhood with various somatic 


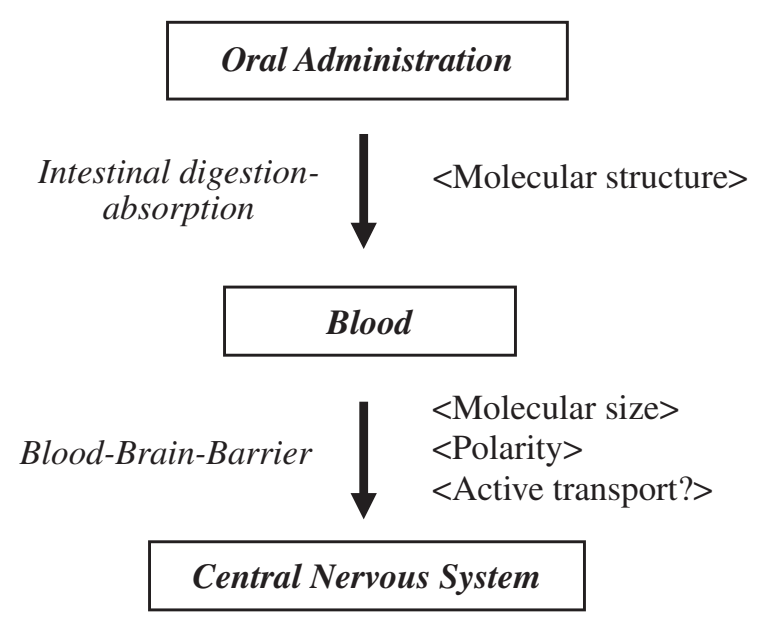

Pharmacokinetics

$>$ Delivery to brain (Oral administration)

Tissue saturation within 3 days

Clearing within 4-7 days (urine)

\section{Biological effects}

Mutant enzyme activity increased

Substrate storage decreased

Neurology (motor) improved

Survival prolonged

\section{Adverse effect?}

No specific clinical abnormality

(1 mM up to 12 months)

Suggested dose for model mouse: $10-30 \mathrm{mg} / \mathrm{kg} / \mathrm{day}$

Intermittent administration?

Prenatal treatment?

Fig. 3. Chaperone effect of NOEV on the $\mathrm{G}_{\mathrm{M} 1}$-gangliosidosis model mouse. After oral administration, the chaperone NOEV enters the bloodstream without intestinal digestion, is delivered to the central nervous system through the blood-brain barrier, and finally exhibits its chaperone activity toward the dormant enzyme protein, achieving biochemical, pathological and clinical effects in $\mathrm{G}_{\mathrm{M} 1^{-}}$ gangliosidosis model mice. No longstanding storage has been observed in mouse cells during and after the NOEV treatment. No recognizable clinical or pathological adverse effects were observed. The effective dose was estimated at $10-30 \mathrm{mg} / \mathrm{kg} / \mathrm{day}$ with ad libitum oral administration of the water solution. The dose may be significantly reduced by intermittent oral administration (once in 2-3 days) for clinical practice. Summarized from refs. 19, 45, and 97.

manifestations. ${ }^{21)}$ The general incidence was estimated at 1:100,000-200,000 live births. ${ }^{39)}$ It was reported to be the 4 th common sphingolipidosis in Turkey. ${ }^{40)}$ Furthermore, there are some ethnic groups with a surprisingly high incidence. ${ }^{21)}$ After our report on $\beta$-galactosidase cDNA cloning, ${ }^{41)}$ extensive mutation data have been accumulated in $\mathrm{G}_{\mathrm{M} 1 \text {-gagliosidosis and Morquio B patients, }}{ }^{21), 42), 43)}$ and currently more than 160 mutations have been identified in HGMD. ${ }^{36)}$ Mutations in $\mathrm{G}_{\mathrm{M} 1 \text {-gangliosi- }}$ dosis patients are heterogeneous and complex. Some common mutations have been identified: p.R482H in Italian patients with infantile $\mathrm{G}_{\mathrm{M} 1}$-gangliosidosis; p.R208C in American patients with infantile $\mathrm{G}_{\mathrm{M} 1^{-}}$ gangliosidosis; p.R201C in Japanese patients with juvenile $\mathrm{G}_{\mathrm{M} 1}$-gangliosidosis; and p.I51T in Japanese patients with adult $\mathrm{G}_{\mathrm{M} 1}$-gangliosidosis. ${ }^{21)}$ Another mutation p.W273L is known to cause Morquio B disease, the second $\beta$-galactosidase deficiency phenotype (generalized skeletal dysplasia). ${ }^{43}$
We started the chaperone experiment on $\beta$ galactosidase immediately after the experiments on $\alpha$-galactosidase A. The first report was published on a newly synthesized organic compound valienamine derivative NOEV as a chemical chaperone for $\beta$ galactosidase toward genetically engineered $\mathrm{G}_{\mathrm{M} 1^{-}}$ gangliosidosis model mice. ${ }^{25), 44)}$ It is a potent competitive inhibitor of $\beta$-galactosidase in vitro, and restores mutant enzyme activities in somatic cells from patients with $\mathrm{G}_{\mathrm{M} 1}$-gangliosidosis. Pharmacokinetic analysis revealed rapid intestinal absorption and renal excretion after oral administration of NOEV. ${ }^{45)}$ It was delivered to the central nervous system through the blood-brain barrier to achieve a high expression of the apparently deficient $\beta$-galactosidase activity in the $\mathrm{G}_{\mathrm{M} 1}$-gangliosidosis model mice. NOEV treatment starting at the early stage of disease resulted in remarkable arrest of neurological progression within a few months with prolongation of survival time (Fig. 3). ${ }^{45)}$ 
Table 2. Chaperone effect of MTD118 on $\mathrm{G}_{\mathrm{M} 1}$-gangliosidosis cells and model mice*

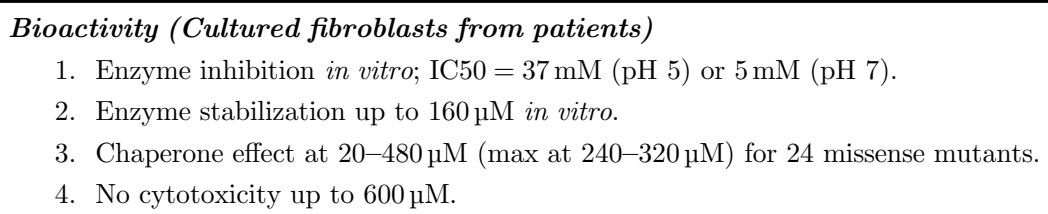

Phamacokinetics ( $G_{M 1}-$ gangliosidosis model mouse)

1. Delivery to the central nervous system by oral administration (water solution).

2. Enhancement of mutant p.R201C activities in the brain (5 or $10 \mathrm{~m}, 1$ week).

3. Reduction of substrate accumulation in neurons.

4. Restoration of autophagic impairment in brain.

*Summarized from refs. 29 and 47.

Recently a new chaperone MTD118, a bicyclic DGJ derivative with an advantage of simpler chemical synthesis as compared to NOEV, ${ }^{46}$ ) was found to show a chaperone spectrum complementary to that of NOEV for some mutant genes (Table 2). ${ }^{29), 47)}$ Thus, the combination of NOEV and MTD118 will cover $60-70 \%$ of patients with $\mathrm{G}_{\mathrm{M} 1}$-gangliosidosis, and hopefully those with Morquio B disease. Galactose was reported to be a potential chemical chaperone in some $\mathrm{G}_{\mathrm{M} 1}$-gangliosidosis mutations as well as in Fabry disease. ${ }^{48)}$

In $\mathrm{G}_{\mathrm{M} 1}$-gangliosidosis, chaperone therapy experiments have been utilized for analysis of pathogenesis in $\mathrm{G}_{\mathrm{M} 1}$-gangliosidosis. ${ }^{49), 50)}$ Autophagy and mitochondrial dysfunction were corrected by NOEV administration to $\mathrm{G}_{\mathrm{M} 1}$-gangliosidosis model mice. The molecular background of chaperone therapy has been analyzed using NOEV and other new chaperone candidates. ${ }^{46), 51), 52)}$ The enzyme-chaperone complex is stable at neutral $\mathrm{pH}$, and dissociates at acidic $\mathrm{pH}$ because of an increase of free binding energy. ${ }^{19), 27)}$

$\alpha$-Glucosidase deficiency (Pompe disease). Pompe disease is a cardiomyopathy with a wide clinical spectrum, occurring at varying ages from early infancy to late adulthood. Abnormal storage of glycogen in the lysosome is caused by lysosomal $\alpha$-glucosidase gene mutations, resulting in enzyme deficiency. ERT has been used particularly for progressive myopathies. Chaperones 1-deoxynojirimycin and its analogues have been tried for chaperone therapy in this disease. ${ }^{53)}$ Combination of chaperone therapy with $N$-(n-butyl)deoxynojirimycin and ERT has been tried in Pompe patients. A remarkable enhancement of the enzyme activity was achieved as compared to the enzyme replacement alone. ${ }^{54)}$ A series of non-iminosugar chaperones were screened in the NIH Small Molecule Repository, and exhibited $\alpha$-glucosidase chaperone activities. ${ }^{55)}$

Furthermore, some non-competitive chaperones have been reported for a few diseases including Pompe disease (see below).

$\boldsymbol{\beta}$-Glucosidase deficiency (Gaucher disease). Gaucher disease is a group of diverse clinical manifestations involving both the central nervous system and extraneural visceral organs, caused by $\beta$-glucosidase gene mutations, resulting in enzyme deficiency and massive storage of glucosylceramide. More than 400 gene mutations have been recorded in HGMD. ${ }^{36)}$ Clinically it is classified into three major phenotypes: chronic non-neuronopathic (adult), acute neuronopathic (infantile), and subacute neuronopathic (juvenile). ERT is available for non-neuronopathic patients, and the clinical effect has been well documented. ${ }^{10)}$ However, neurological manifestations have not been controlled by this therapeutic approach. After the first report on a chemical chaperone $N$-(n-nonyl)deoxynojirimycin, ${ }^{56)}$ we also tried to develop chaperone compounds for the brain damage in Gaucher disease. $N$-octyl- $\beta$-valienamine, an epimer of NOEV, was found as a new chaperone compound for this disease. ${ }^{57)}$ Although its effectiveness was confirmed in the cell culture system, animal studies were not carried out since appropriate animal models have not been available to us as yet.

Several different approaches have been tried to develop new chaperones for Gaucher disease. High throughput screening of a collection of compounds for the mutant Gaucher enzyme (p.N370S) revealed 14 new lead inhibitors and 30 lead activators. ${ }^{58)}$ Another group reported that a series of N-substituted epsilonhexonolactams showed enhancements to p.N370S mutant $\beta$-glucosidase activity. ${ }^{59)}$ Some synthetic quinazoline analogues were $\beta$-glucosidase inhibitors 
with chaperone activity. ${ }^{60)}$ Furthermore, picomolar concentrations of aminocyclitols are sufficient to enhance activity in the p.L444P variant, which produces a severe neuronopathic form of Gaucher disease. ${ }^{61)}$

Some non-inhibitory pyrazolpyrimidine series compounds were found to be allosteric enzyme activators (non-competitive chaperones) without inhibition of the enzyme activity at high concentrations $^{62)}$ (see below).

Recently ambroxol hydrochloride, a commercially available expectorant drug, was reported to be an excellent chaperone candidate for Gaucher disease. ${ }^{63)}$ It was found by a systematic screening of 1040 FDA approved drugs. This is a pH-dependent mixed-type inhibitor of $\beta$-glucosidase. The p.N370S and p.F213I mutant enzyme activities were enhanced by ambroxol in Gaucher fibroblasts. Subsequently we tried to treat neuronopathic Gaucher patients with p.N188S mutation by long-term oral administration of ambroxol hydrochloride. They showed remarkable neurological improvements, particularly oculomotor dysfunction and myoclonus. Further studies are in progress [Narita et al., unpublished data]. Preliminary results also on non-neuronopathic Gaucher disease were reported from Israel. ${ }^{64)}$

$\boldsymbol{\beta}$-Hexosaminidase deficiency $\left(\mathrm{G}_{\mathrm{M} 2}\right.$-gangliosidoses). $\mathrm{G}_{\mathrm{M} 2}$-Gangliosidoses are a group of neurogenetic diseases due to $\beta$-hexosaminidase deficiency (Tay-Sachs disease and Sandhoff disease). Two genes are responsible for the pathogenesis of these diseases. The HEXA gene mutation leads to the mutant $\alpha$-subunit of the enzyme, causing $\beta$-hexosaminidase $\mathrm{A}(\alpha \beta)$ deficiency in Tay-Sachs disease, and the HEXB gene mutation, causing both $\beta$-hexosaminidases $\mathrm{A}(\alpha \beta)$ and $\mathrm{B}(\beta \beta)$ deficiency in Sandhoff disease. Some enzyme inhibitors restored the catalytic activity in fibroblasts. ${ }^{65)}$ Among them an antimalarial drug pyrimethamine was found as the most potent inhibitor. ${ }^{66)}$ It binds to the active site of $\beta$-hexosaminidase $\mathrm{B},{ }^{67}$ ) and was subjected to clinical trials for $\mathrm{G}_{\mathrm{M} 2}$-Gangliosidoses as monotherapy for either of the $\mathrm{G}_{\mathrm{M} 2}$-gangliosidosis patients. ${ }^{68)}$ Pyrimethamine treatment enhanced leukocyte enzyme $\beta$ hexosaminidase A activity but significant clinical side effects were experienced in most patients at or above $75 \mathrm{mg}$ doses per day. Further plans are underway to extend this clinical approach.

\section{Chaperone therapy for non-lysosomal diseases}

Starting with a few lysosomal and non-lysosomal diseases, such as cystic fibrosis and some neuro- degenerative disease as candidate targets, many other types of genetic and non-genetic diseases have been suggested to be the candidates for chaperone therapy. In Table 3, the diseases are listed for possible chaperone therapy by correction and normalization of misfolding proteins in genetic or nongenetic diseases, or protein modifications in other pathological conditions such as prion disease ${ }^{69)}$ or viral infection (capsid assembly). ${ }^{70}$ The list includes a large number of diseases with varying pathogenesis and clinical manifestations. At present, however, none of them has been established for clinical practice as yet, although some diseases have reached the stage of human clinical studies.

Among them two classical genetic diseases are taken for a short overview. Cystic fibrosis was the first non-lysosomal disease that attracted interest in misfolding of a transmembrane conductance regulator (CFTR). The most common mutation p.F508del causes misfolding of this protein, resulting in rapid molecular degradation. One strategy to treat this pathophysiology was to protect against proteolytic cleavage by the use of molecular stabilizers (chemical chaperones) such as glycerol, trimethylamine $\mathrm{N}$-oxide and deuterated water. ${ }^{30), 71)}$ In other reports, the cellular trafficking was successfully restored in the mutant cells. Two groups of compounds have been reported: benzo[c]quinolizinium compounds, selective inhibitors of the p.F508del-CFTR protein, ${ }^{72), 73)}$ and correctors promoting the proper folding of p.F508delCFTR. $^{74)}$ Further high-throughput screening revealed some quinazoline-based compounds as candidate chaperones. ${ }^{75)-78)}$

Phenylketonuria is a classical inborn error of metabolism caused by mutations of the gene encoding phenylalanine hydroxylase. Most of them lead to protein folding defects, resulting in enzyme deficiency due to increased protein degradation. The enzyme cofactor (6R)-1-erythro-5,6,7,8-tetrahydrobiopterin showed a therapeutic chaperone effect in some patients. ${ }^{79)}$ Subsequent studies identified new noninhibitory chaperones ${ }^{80), 81)}$ (see below).

\section{Emerging concept of chaperone therapies}

Inhibitory chaperone therapy. The trial of chaperone therapy was started for some lysosomal diseases (Fabry disease, $\mathrm{G}_{\mathrm{M} 1}$-gangliosidosis, Gaucher disease $)^{19)}$ and non-lysosomal diseases such as cystic fibrosis. The intralysosomal environment is uniquely acidic. We were able to utilize the different $\mathrm{pH}$ environments at two compartments, ER/Golgi and the lysosome, for chaperone therapy. A competitive 
Table 3. Diseases reported for possible chaperone therapy

\begin{tabular}{|c|c|c|}
\hline Pathophysiology & Disease & Chaperone type* \\
\hline \multirow[t]{15}{*}{ Lysosome } & Fabry disease $\mathrm{F}^{23), 24), 37)}$ & $1 \mathrm{a}$ \\
\hline & $\mathrm{G}_{\mathrm{M} 1}$-gangliosidosis ${ }^{25), 29), 45), 47), 97)}$ & $1 \mathrm{a}$ \\
\hline & Morquio B disease ${ }^{25), 29), 98)}$ & $1 \mathrm{a}$ \\
\hline & Krabbe disease $^{99), 100)}$ & $1 \mathrm{a}$ \\
\hline & Gaucher disease $^{56), 62), 63), 101)}$ & $1 \mathrm{a}, 1 \mathrm{~b}$ \\
\hline & Schindler-Kanzaki disease ${ }^{102)}$ & $1 \mathrm{a}$ \\
\hline & $\mathrm{G}_{\mathrm{M} 2}$-gangliosidosis ${ }^{65), 103)}$ & $1 \mathrm{a}$ \\
\hline & Metachromatic leukodystrophy ${ }^{11)}$ & $1 \mathrm{a}, 1 \mathrm{~b}$ \\
\hline & Pompe disease $^{53), 83), 104), 105)}$ & $1 \mathrm{a}, 1 \mathrm{~b}$ \\
\hline & Niemann-Pick A/B disease ${ }^{93), 94)}$ & 2 \\
\hline & Niemann-Pick C disease ${ }^{106), 107)}$ & $1 b$ \\
\hline & Mucolipidosis IV ${ }^{108)}$ & $1 \mathrm{~b}$ \\
\hline & Late infantile ceroid lipofuscinosis $\left(\right.$ NCL2) ${ }^{109)}$ & $1^{* *}$ \\
\hline & Juvenile neuronal ceroid lipofuscinosis (NCL3; Batten) ${ }^{110)}$ & $1^{* *}$ \\
\hline & Mucopolysaccharidosis type 3 (Sanfilippo) $)^{111)-113)}$ & $1 \mathrm{a}$ \\
\hline \multirow[t]{2}{*}{ Peroxisome } & Adrenoleukodystrophy ${ }^{114)}$ & $1 \mathrm{a}$ \\
\hline & Zellweger disease ${ }^{115)}$ & $1 b$ \\
\hline Mitochondrion & Argyrophilic grain disease ${ }^{116)}$ & 2 \\
\hline Amino acid & Phenylketonuria ${ }^{80), 81), 95), 117)}$ & $1 \mathrm{~b}, 2$ \\
\hline \multirow[t]{3}{*}{ Organic acid } & Hyperoxaluria $^{82), 118)}$ & $1 b$ \\
\hline & Homocystinuria $^{118)}$ & $1^{* *}$ \\
\hline & Methylmalonic aciduria $^{85)}$ & $1 b$ \\
\hline \multirow[t]{3}{*}{ Carbohydrate } & Type 1 galactosemia ${ }^{119)}$ & $1 * *$ \\
\hline & MAN1B1-glycoprotein synthesis disorder ${ }^{120)}$ & $1 b$ \\
\hline & Hyperinsulinemic hypoglycemia ${ }^{5)}$ & $1 b$ \\
\hline \multirow[t]{9}{*}{ Neurodegeneration } & Neurodegenerative diseases ${ }^{87), 91), 121)}$ & 2 \\
\hline & Parkinson disease $\mathrm{e}^{91), 92), 122)-125)}$ & 2 \\
\hline & Alzheimer disease ${ }^{91), 124), 126), 127)}$ & 2 \\
\hline & Huntington disease ${ }^{91), 128), 129)}$ & 2 \\
\hline & Amyotrophic lateral sclerosis 91$), 130$ ) & 2 \\
\hline & Type 1 spinocerebellar ataxia ${ }^{90)}$ & 2 \\
\hline & 1-DOPA-responsive dystonia ${ }^{117}$ ) & $1 b$ \\
\hline & Prion disease ${ }^{69), 131), 132)}$ & $1 b$ \\
\hline & Creutzfeld-Jakob disease $^{6)}$ & 2 \\
\hline Congenital myopathy & Myosinopathies ${ }^{133)}$ & 2 \\
\hline
\end{tabular}

Continued on next page.

enzyme inhibitor (chaperone) binds to the active site of the target enzyme at ER under the neutral condition to form a stable complex, which is transported to the lysosome, where the complex dissociates under the acidic condition, due to less strong molecular binding, in the lysosome. The free mutant enzyme remains stable and becomes catalytically active. ${ }^{19)}$

This is the concept of inhibitory chaperone therapy. An in vitro inhibitor acts paradoxically as an intracellular enhancer at low concentrations. We should select an appropriate concentration of the chaperone compound in question in order to attain a chaperone activity without adverse (inhibitory) effect to the cell. Chaperone therapy will be more safely conducted if a non-inhibitory compound is available for restoration of an inactive protein caused by misfolding, although most of the inhibitory chaperones discovered till present show a wide range of efficacy in the cells, animals, and human patients without significantly adverse effects.

Non-inhibitory (allosteric) chaperone therapy. Recently enzyme cofactors were reported to 
Continued.

\begin{tabular}{|c|c|c|}
\hline Pathophysiology & Disease & Chaperone type* \\
\hline \multirow[t]{12}{*}{ Other genetic diseases } & Cystic fibrosis ${ }^{30), 71), 134)}$ & $1 b$ \\
\hline & Wilson disease $^{135)}$ & 2 \\
\hline & Familial intrahepatic cholestasis ${ }^{136), 137)}$ & $1 b$ \\
\hline & Nephrogenic diabetes insipidus ${ }^{138), 139)}$ & $1 b$ \\
\hline & Retinitis pigmentosa ${ }^{140)-142)}$ & $1 \mathrm{~b}$ \\
\hline & Keratinopathy ${ }^{143)}$ & $1 \mathrm{~b}$ \\
\hline & Epidermolysis bullosa simplex ${ }^{144)}$ & $1 b$ \\
\hline & G-protein-coupled receptor diseases ${ }^{145)-149)}$ & $1 b$ \\
\hline & Thyroid hormone activating enzyme type 2 deiodinase deficiency ${ }^{150)}$ & $1 \mathrm{~b}$ \\
\hline & Hypogonadotropic hypogonadism ${ }^{5)}$ & $1 b$ \\
\hline & Early-onset obesity caused by melanocortin- 4 receptor ${ }^{151)}$ & $1 b$ \\
\hline & Desmin-related cardiomyopathy ${ }^{152)}$ & $1 \mathrm{~b}$ \\
\hline \multirow[t]{2}{*}{ Infection } & Human immunodeficiency virus ${ }^{70)}$ & $1 b$ \\
\hline & Cholera $^{153)}$ & $1 \mathrm{~b}$ \\
\hline Malignancy & Multiple myeloma ${ }^{154)}$ & $1 \mathrm{a}$ \\
\hline Aging & Organ aging ${ }^{155)}$ & 2 \\
\hline
\end{tabular}

$*_{1} \mathrm{a}=$ low molecule chaperone, inhibitory; $1 \mathrm{~b}=$ low molecule chaperone, non-inhibitory; $2=$ protein chaperone.

**Theoretical prediction; experimental data not shown.

be chaperones in some diseases; tetrahydrobiopterin in phenylketonuria, ${ }^{81)}$ and pyridoxal $5^{\prime}$-phosphate and aminooxyacetic acid in primary hyperoxaluria type $1{ }^{82)}$ In line with these findings, new chaperones without inhibitory bioactivity have been identified and called non-inhibitory chaperones, ${ }^{62)}$ allosteric chaperones, ${ }^{83)}$ or non-competitive chaperones. ${ }^{84)}$ They are non-substrate-like compounds that exhibit allosteric chaperone activities, not necessarily binding to the active site of the enzyme.

A set of pyrazolopyrimidines were identified by high throughput screening as activators of $\beta$-glucosidase responsible for Gaucher disease. ${ }^{62)}$ Additional studies revealed that the activity in assays using p.N370S mutant or wild type spleen homogenate preparations was 3-10 fold better than purified enzyme conditions. This biological activity was specific to glucocerebrosidase.

$\mathrm{N}$-acetylcysteine (NAC) was reported to be a novel allosteric chaperone for $\alpha$-glucosidase in Pompe disease. It improved the stability and catalytic activity of recombinant $\alpha$-glucosidase as a function of $\mathrm{pH}$ and temperature without disrupting its catalytic activity. NAC does not interact with the catalytic domain of the enzyme. The culture cells and model mice responded better when NAC was combined with ERT. ${ }^{83)}$

Additionally the candidate molecules were found by an in silico-in vitro-in vivo approach, leading to stabilization of the mutant enzyme p.V106A without relevant inhibitory effects in phenylketonuria. ${ }^{81)}$ However, ligand-binding affinity was mutation specific. Also high-throughput ligand screening revealed a compound that significantly increased the mutant enzyme activity in methylmalonic aciduria and did not act as an inhibitor of the purified enzyme protein. ${ }^{85)}$

Molecular chaperone therapy. There are reports to utilize endogenous heat shock proteins (Hsp) for stabilization of mutant proteins in some diseases by using small molecules as molecular chaperone inducers, mainly focusing on neurodegenerative diseases; polyglutamine (polyQ) diseases and tauopathies. ${ }^{6), 86)-89)}$ Major classes of Hsp are Hsp100, Hsp90, Hsp70, Hsp60 and the small Hsp. These molecular chaperones have important damagecontrol functions during and following stress. Under in vitro conditions, many chaperones can bind chemically unfolded polypeptides and prevent aggregation. They are also involved in aggregate solubilization.

Overexpression of Hsp70 was found to be effective for type 1 spinocerebellar ataxia. ${ }^{90)}$ Chaperones Hsp70 and Hsp40 may play a role in some human neurodegenerative disorders like Parkinson disease and Alzheimer disease. ${ }^{86)}$

A variety of molecular chaperones such as Hsp70 and Hsp40 have been demonstrated to exert therapeutic effects against various experimental models of polyQ diseases. In addition, small chemical activators of heat shock transcription factor 1 , such 
Table 4. Chaperone therapies for protein misfolding diseases

1. Low molecule chaperone (exogenous) = pharmacological chaperone; chemical chaperone

(a) Competitive inhibitor (inhibitory chaperone)

(b) Non-competitive stabilizer (non-inhibitory/non-competitive/allosteric chaperone)

Target diseases: Both genetic and non-genetic (neuronopathic or non-neuronopathic)

2. Protein chaperone (endogenous) = molecular chaperone induced by small molecules

Target diseases: Neurodegenerative diseases (polyQ diseases, tauopathies)

Myopathies (myosin chaperone)

Wilson disease (copper chaperone)

as geldanamycin and its derivative 17-allylamino17-demethoxygeldanamycin, are effective not only in polyQ disease models but also in other neurodegenerative disease models by inducing multiple endogenous molecular chaperones. It is expected that blood-brain-barrier-permeable molecular chaperone inducers become available as new drugs for neurodegenerative diseases in the near future. ${ }^{91)}$

Hsp70 and its co-chaperone can arrest neurodegeneration by preventing $\alpha$-synuclein misfolding, oligomerization and aggregation in vitro and in Parkinson disease animal models. Hsp104 is able to resolve disordered protein aggregates and cross $\beta$ amyloid conformers. These chaperones have a complementary effect and can be a target for therapeutic intervention in Parkinson disease. ${ }^{92)}$

Hsp70 is known to inhibit lysosomal membrane permeabilization, a hallmark of stress-induced cell death. Niemann-Pick disease (A and B) caused by sphingomyelinase deficiency is associated with a marked decrease in lysosomal stability. It is possible that this phenotype can be effectively corrected by treatment utilizing Hsp70. ${ }^{93), 94)}$

In a study, Hsp70/Hsp40, Hsp90 as well as a pharmacological chaperone, 3-amino-2-benzyl7-nitro-4-(2-quinolyl)-1,2-dihydroisoquinolin-1-one, partly inhibited the self-association process of the enzyme phenylalanine hydroxylase, suggesting a possible approach to phenylketonuria therapy. $\left.{ }^{95}\right)^{\circ}$

The research in this direction will reveal a new scope for chaperone therapy in future. In Table 4, possible chaperone therapies are listed utilizing small molecules or protein chaperones induced by small molecules for various types of misfolding diseases, genetic or non-genetic, and neuronopathic or non-neuronopathic. Diverse approaches are expected to find new types of chaperone compounds with different molecular actions toward misfolding proteins.

\section{Conclusion}

Chaperone therapy has been proposed mainly as a new therapeutic approach to neuronopathic lysosomal diseases and non-neuronopathic genetic diseases such as cystic fibrosis. Currently ERT is widely used for extraneural tissue pathology with successful achievements in lysosomal diseases. The effect of ERT on non-neural tissues has been well documented, but two major disadvantages are present: intravenous administration for life at regular intervals, and poor effect to the central nervous system pathology. As stated above, some clinical experiments are in progress, including intrathecal administration of the enzyme protein.

A second clinical approach has been proposed to reduce the storage substrates by inhibition of glucosyltransferase: substrate reduction therapy. ${ }^{96)}$ This new approach is meant to diminish glucosylceramide in the cell, the first step product of glycosphingolipid synthesis. In fact this trial has been reported not only for Gaucher disease with glucosylceramide storage but also for Niemann-Pick C disease, Sandhoff disease and other diseases with substrate storage of more complex types. However, this approach inevitably deprives somatic cells of biologically active glycosphingolipids to some extent, possibly ensuing dysfunction of various types in somatic cells. In fact clinical side effects have been recorded at therapeutic dose levels even in healthy individuals, particularly headache and diarrhea. This is the most important issue when this therapeutic approach is discussed for future clinical practice. At present new compounds are on clinical trial with less adverse effects.

Chaperone therapy, originally proposed as chemical chaperone therapy, has been also called pharmacological chaperone therapy or enzyme enhancement therapy at present. Advantage of this 
new approach is non-invasive oral drug administration to enhance apparently missing enzyme activity and to restore normal metabolic turnover in cells and tissues. Moreover, small molecule chaperones reach the central nervous system, thus potentially correcting pathophysiology of currently non-treatable genetic brain diseases. A drawback is that it is a mutation-specific drug therapy, and we admit that not all patients under the diagnosis of a single genetic disease can be treated by one chaperone drug, although at least one-third to one-half of patients can be the target of this therapeutic trial. In addition combination of two or more chaperone compounds will reach a broader chaperone spectrum at least to two-thirds of patients. A combination therapy with ERT may be useful.

Neurological effectiveness has been confirmed for $\mathrm{G}_{\mathrm{M} 1}$-gangliosidosis model mice (NOEV) and human Gaucher patients [ambroxol; Narita et al., unpublished data|. No clinically recognizable adverse effects have been observed so far at the effective doses in both mice and humans. We hope that further experiments will confirm validity of this new therapeutic concept in clinical practice in the near future.

\section{Acknowledgments}

This work was supported by grants from the Ministry of Education, Culture, Science, Sports, and Technology of Japan (13680918, 14207106) and from the Ministry of Health, Labour and Welfare of Japan (H10-No-006, H14-Kokoro-017, H17-Kokoro-019, H20-Kokoro-022, H19-Nanji-Ippan-002, H22-NanjiIppan-002), and a grant from Japan Science and Technology Agency (AS232Z00009G). I thank all collaborators contributing to this research project at various institutions.

\section{References}

1) Hamosh, A. Online Mendelian Inheritance in Man (OMIM). An Online Catalog of Human Genes and Genetic Disorders. Baltimore: McKusickNathans Institute of Genetic Medicine, Johns Hopkins University. Available from: http:// www.omim.org/.

2) Thomas, P.J., Qu, B.H. and Pedersen, P.L. (1995) Defective protein folding as a basis of human disease. Trends Biochem. Sci. 20, 456-459.

3) Gregersen, N., Bross, P., Andrese, B.S., Pedersen, C.B., Corydon, T.J. and Bolund, L. (2001) The role of chaperone-assisted folding and quality control in inborn errors of metabolism: protein folding disorders. J. Inherit. Metab. Dis. 24, 189212 .

4) Cohen, F.E. and Kelly, J.W. (2003) Therapeutic approaches to protein-misfolding diseases. Nature 426, 905-909.

5) Bernier, V., Lagace, M., Bichet, D.G. and Bouvier, M. (2004) Pharmacological chaperones: potential treatment for conformational diseases. Trends Endocrinol. Metab. 15, 222-228.

6) Chaudhuri, T.K. and Paul, S. (2006) Proteinmisfolding diseases and chaperone-based therapeutic approaches. FEBS J. 273, 1331-1349.

7) Leandro, P. and Gomes, C.M. (2008) Protein misfolding in conformational disorders: rescue of folding defects and chemical chaperoning. Mini Rev. Med. Chem. 8, 901-911.

8) Suzuki, Y. (2013) Chaperone therapy update: Fabry disease, $\mathrm{G}_{\mathrm{M} 1}$-gangliosidosis and Gaucher disease. Brain Dev. 35, 515-523.

9) Brady, R.O. (2006) Emerging strategies for the treatment of hereditary metabolic storage disorders. Rejuvenation Res. 9, 237-244.

10) Desnick, R.J. and Schuchman, E.H. (2012) Enzyme replacement therapy for lysosomal diseases: lessons from 20 years of experience and remaining challenges. Annu. Rev. Genomics Hum. Genet. 13, 307-335.

11) Patil, S.A. and Maegawa, G.H. (2013) Developing therapeutic approaches for metachromatic leukodystrophy. Drug Des. Devel. Ther. 7, 729-745.

12) Vite, C.H., Wang, P., Patel, R.T., Walton, R.M., Walkley, S.U., Sellers, R.S., Ellinwood, N.M., Cheng, A.S., White, J.T., O'Neill, C.A. and Haskins, M. (2011) Biodistribution and pharmacodynamics of recombinant human $\alpha$-L-iduronidase (rhIDU) in mucopolysaccharidosis type Iaffected cats following multiple intrathecal administrations. Mol. Genet. Metab. 103, 268-274.

13) Vera, M., Le, S., Kan, S.H., Garban, H., Naylor, D., Mlikotic, A., Kaitila, I., Harmatz, P., Chen, A. and Dickson, P. (2013) Immune response to intrathecal enzyme replacement therapy in mucopolysaccharidosis I patients. Pediatr. Res. 74, 712-720.

14) Dickson, P.I., Ellinwood, N.M., Brown, J.R., Witt, R.G., Le, S.Q., Passage, M.B., Vera, M.U. and Crawford, B.E. (2012) Specific antibody titer alters the effectiveness of intrathecal enzyme replacement therapy in canine mucopolysaccharidosis I. Mol. Genet. Metab. 106, 68-72.

15) Sohn, Y.B., Lee, J., Cho, S.Y., Kim, S.J., Ko, A.R., Nam, M.H. and Jin, D.K. (2013) Improvement of CNS defects via continuous intrathecal enzyme replacement by osmotic pump in mucopolysaccharidosis type II mice. Am. J. Med. Genet. 161A, 1036-1043.

16) Auclair, D., Finnie, J., Walkley, S.U., White, J., Nielsen, T., Fuller, M., Cheng, A., O'Neill, C.A. and Hopwood, J.J. (2012) Intrathecal recombinant human 4-sulfatase reduces accumulation of glycosaminoglycans in dura of mucopolysaccharidosis VI cats. Pediatr. Res. 71, 39-45.

17) Sakuraba, H., Aoyagi, T. and Suzuki, Y. (1982) Galactosialidosis ( $\beta$-galactosidase-neuraminidase deficiency): a possible role of serine-thiol proteases 
in the degradation of $\beta$-galactosidase molecules. Clin. Chim. Acta 125, 275-282.

18) Ko, Y.M., Yamanaka, T., Umeda, M. and Suzuki, Y. (1983) Effects of thiol protease inhibitors on intracellular degradation of exogenous $\beta$-galactosidase in cultured human skin fibroblasts. Exp. Cell Res. 148, 525-529.

19) Suzuki, Y., Ogawa, S. and Sakakibara, Y. (2009) Chaperone therapy for neuronopathic lysosomal diseases: competitive inhibitors as chemical chaperones for enhancement of mutant enzyme activities. Perspect. Med. Chem. 3, 7-19.

20) Conzelmann, E. and Sandhoff, K. (1983) Partial enzyme deficiencies: residual activities and the development of neurological disorders. Dev. Neurosci. 6, 58-71.

21) Suzuki, Y., Nanba, E., Matsuda, J., Higaki, K. and Oshima, A. (2013) $\beta$-Galactosidase Deficiency $(\beta$ Galactosidosis): $\mathrm{G}_{\mathrm{M} 1}$-Gangliosidosis and Morquio B disease. McGraw-Hill, New York, Available from: http://www.ommbid.com/.

22) Ishii, S., Kase, R., Sakuraba, H. and Suzuki, Y. (1993) Characterization of a mutant $\alpha$-galactosidase gene product for the late-onset cardiac form of Fabry disease. Biochem. Biophys. Res. Commun. 197, 1585-1589.

23) Okumiya, T., Ishii, S., Takenaka, T., Kase, R., Kamei, S., Sakuraba, H. and Suzuki, Y. (1995) Galactose stabilizes various missense mutants of $\alpha$-galactosidase in Fabry disease. Biochem. Biophys. Res. Commun. 214, 1219-1224.

24) Fan, J.Q., Ishii, S., Asano, N. and Suzuki, Y. (1999) Accelerated transport and maturation of lysosomal $\alpha$-galactosidase A in Fabry lymphoblasts by an enzyme inhibitor. Nat. Med. 5, 112-115.

25) Matsuda, J., Suzuki, O., Oshima, A., Yamamoto, Y., Noguchi, A., Takimoto, K., Itoh, M., Matsuzaki, Y., Yasuda, Y., Ogawa, S., Sakata, Y., Nanba, E., Higaki, K., Ogawa, Y., Tominaga, L., Ohno, K., Iwasaki, H., Watanabe, H., Brady, R.O. and Suzuki, Y. (2003) Chemical chaperone therapy for brain pathology in $\mathrm{G}_{\mathrm{M} 1}$-gangliosidosis. Proc. Natl. Acad. Sci. U.S.A. 100, 15912-15917.

26) Suzuki, Y. (2006) $\beta$-Galactosidase deficiency: an approach to chaperone therapy. J. Inherit. Metab. Dis. 29, 471-476.

27) Jo, H., Yugi, K., Ogawa, S., Suzuki, Y. and Sakakibara, Y. (2010) Molecular basis of chemical chaperone effects of $N$-octyl- $\beta$-valienamine on human $\beta$-glucosidase in low/neutral $\mathrm{pH}$ conditions. J. Proteomics Bioinformat. 3, 104-112.

28) Ishii, S. (2012) Pharmacological chaperone therapy for Fabry disease. Proc. Jpn. Acad., Ser. B, Phys. Biol. Sci. 88, 18-30.

29) Higaki, K., Ninomiya, H., Suzuki, Y. and Nanba, E. (2013) Candidate molecules for chemical chaperone therapy of $\mathrm{G}_{\mathrm{M} 1}$-gangliosidosis. Future Med. Chem. 5, 1551-1558.

30) Brown, C.R., Hong-Brown, L.Q., Biwersi, J., Verkman, A.S. and Welch, W.J. (1996) Chemical chaperones correct the mutant phenotype of the delta F508 cystic fibrosis transmembrane con- ductance regulator protein. Cell Stress Chaperones 1, 117-125.

31) Oxford English Dictionary, 2nd ed. Oxford: Oxford University Press; 1989.

32) Laskey, R.A., Honda, B.M., Mills, A.D. and Finch, J.T. (1978) Nucleosomes are assembled by an acidic protein which binds histones and transfers them to DNA. Nature 275, 416-420.

33) Branford White, C.J. (1980) Sulphated glycoproteins in synaptosomes. Neurosci. Lett. 16, 307311.

34) Smart, Y.C., Cripps, A.W., Clancy, R.L., Roberts, T.K., Lopata, A. and Shutt, D.A. (1981) Detection of an immunosuppressive factor in human preimplantation embryo cultures. Med. J. Aust. 1, 78-79.

35) Nancarrow, C.D., Wallace, A.L. and Grewal, A.S. (1981) The early pregnancy factor of sheep and cattle. J. Reprod. Fertil. Suppl. 30, 191-199.

36) The human gene mutation database (HGMD). Cardiff University, 2012. Available from: http:// www.hgmd.cf.ac.uk.

37) Frustaci, A., Chimenti, C., Ricci, R., Natale, L., Russo, M.A., Pieroni, M., Eng, C.M. and Desnick, R.J. (2001) Improvement in cardiac function in the cardiac variant of Fabry's disease with galactose-infusion therapy. N. Engl. J. Med. 345, $25-32$.

38) Tominaga, L., Ogawa, Y., Taniguchi, M., Ohno, K., Matsuda, J., Oshima, A., Suzuki, Y. and Nanba, E. (2001) Galactonojirimycin derivatives restore mutant human $\beta$-galactosidase activities expressed in fibroblasts from enzyme-deficient knockout mouse. Brain Dev. 23, 284-287.

39) Meikle, P.J., Hopwood, J.J., Clague, A.E. and Carey, W.F. (1999) Prevalence of lysosomal storage disorders. JAMA 281, 249-254.

40) Ozkara, H.A. and Topcu, M. (2004) Sphingolipidoses in Turkey. Brain Dev. 26, 363-366.

41) Oshima, A., Tsuji, A., Nagao, Y., Sakuraba, H. and Suzuki, Y. (1988) Cloning, sequencing, and expression of cDNA for human $\beta$-galactosidase. Biochem. Biophys. Res. Commun. 157, 238-244.

42) Yoshida, K., Oshima, A., Shimmoto, M., Fukuhara, Y., Sakuraba, H., Yanagisawa, N. and Suzuki, Y. (1991) Human $\beta$-galactosidase gene mutations in $\mathrm{G}_{\mathrm{M} 1}$-gangliosidosis: a common mutation among Japanese adult/chronic cases. Am. J. Hum. Genet. 49, 435-442.

43) Oshima, A., Yoshida, K., Shimmoto, M., Fukuhara, Y., Sakuraba, H. and Suzuki, Y. (1991) Human $\beta$-galactosidase gene mutations in Morquio $\mathrm{B}$ disease. Am. J. Hum. Genet. 49, 1091-1093.

44) Ogawa, S., Matsunaga, Y.K. and Suzuki, Y. (2002) Chemical modification of the $\beta$-glucocerebrosidase inhibitor $N$-octyl- $\beta$-valienamine: synthesis and biological evaluation of 4-epimeric and 4-O( $\beta$-D-galactopyranosyl) derivatives. Bioorg. Med. Chem. 10, 1967-1972.

45) Suzuki, Y., Ichinomiya, S., Kurosawa, M., Matsuda, J., Ogawa, S., Iida, M., Kubo, T., Tabe, M., Itoh, M., Higaki, K., Nanba, E. and Ohno, K. (2012) 
Therapeutic chaperone effect of $N$-octyl-4-epi- $\beta$ valienamine on murine $\mathrm{G}_{\mathrm{M} 1}$-gangliosidosis. Mol. Genet. Metab. 106, 92-98.

46) Aguilar-Moncayo, M., Takai, T., Higaki, K., MenaBarragán, T., Hirano, Y., Yura, K., Li, L., Yu, Y., Ninomiya, H., García-Moreno, M.I., Ishii, S., Sakakibara, Y., Ohno, K., Nanba, E., Ortiz Mellet, C., García Fernández, J.M. and Suzuki, Y. (2012) Tuning glycosidase inhibition through aglycone interactions: pharmacological chaperones for Fabry disease and $\mathrm{G}_{\mathrm{M} 1}$-gangliosidosis. Chem. Commun. (Camb.) 48, 6514-6516.

47) Takai, T., Higaki, K., Aguilar-Moncayo, M., MenaBarragan, T., Hirano, Y., Yura, K., Yu, L., Ninomiya, H., Garcia-Moreno, M.I., Sakakibara, Y., Ohno, K., Nanba, E., Ortiz Mellet, C., Garcia Fernandez, J.M. and Suzuki, Y. (2013) A bicyclic 1-deoxygalactonojirimycin derivative as a novel pharmacological chaperone for $\mathrm{G}_{\mathrm{M} 1}$-gangliosidosis. Mol. Ther. 21, 526-532.

48) Caciotti, A., Donati, M.A., d'Azzo, A., Salvioli, R., Guerrini, R., Zammarchi, E. and Morrone, A. (2009) The potential action of galactose as a "chemical chaperone": increase of $\beta$-galactosidase activity in fibroblasts from an adult $\mathrm{G}_{\mathrm{M} 1}$-gangliosidosis patient. Eur. J. Paediatr. Neurol. 13, 160164 .

49) Takamura, A., Higaki, K., Kajimaki, K., Otsuka, S., Ninomiya, H., Matsuda, J., Ohno, K., Suzuki, Y. and Nanba, E. (2008) Enhanced autophagy and mitochondrial aberrations in murine $\mathrm{G}_{\mathrm{M} 1}$-gangliosidosis. Biochem. Biophys. Res. Commun. 367, 616-622.

50) Takamura, A., Higaki, K., Ninomiya, H., Takai, T., Matsuda, J., Iida, M., Ohno, K., Suzuki, Y. and Nanba, E. (2011) Lysosomal accumulation of Trk protein in brain of $\mathrm{G}_{\mathrm{M} 1}$-gangliosidosis mouse and its restoration by chemical chaperone. J. Neurochem. 118, 399-406.

51) Ohto, U., Usui, K., Ochi, T., Yuki, K., Satow, Y. and Shimizu, T. (2012) Crystal structure of human $\beta$-galactosidase: structural basis of $\mathrm{G}_{\mathrm{M}^{-}}$ gangliosidosis and Morquio B diseases. J. Biol. Chem. 287, 1801-1812.

52) Suzuki, H., Ohto, U., Higaki, K., Mena-Barragán, T., Aguilar-Moncayo, M., Ortiz Mellet, C., Nanba, E., Garcia Fernandez, J.M., Suzuki, Y. and Shimizu, T. (2014) Structural basis of pharmacological chaperoning for human $\beta$-galactosidase. J. Biol. Chem. (in press).

53) Okumiya, T., Kroos, M.A., Vliet, L.V., Takeuchi, H., Van der Ploeg, A.T. and Reuser, A.J. (2007) Chemical chaperones improve transport and enhance stability of mutant $\alpha$-glucosidases in glycogen storage disease type II. Mol. Genet. Metab. 90, 49-57.

54) Parenti, G., la Marca, G., Fecarotta, S., Donati, M.A., Mrandi, L.O., Morandi, L.O., Ravaglia, S., Danesino, C., Moglia, A., Ombrone, D., Della Casa, R., Ascione, S., Rosa, M., Carbone, M.T., Concolino, D., Agovino, T., Porto, C., Rossi, B. and Andria, G. (2013) Combined pharmacological chaperone therapy and enzyme replacement therapy in patients with Pompe disease. J. Inherit. Metab. Dis. 36, S93.

55) Xia, B., Asif, G., Arthur, L., Pervaiz, M.A., Li, X., Liu, R., Cummings, R.D. and He, M. (2013) Oligosaccharide analysis in urine by MALDI-TOF mass spectrometry for the diagnosis of lysosomal storage diseases. Clin. Chem. 59, 1357-1368.

56) Sawkar, A.R., Cheng, W.C., Beutler, E., Wong, C.H., Balch, W.E. and Kelly, J.W. (2002) Chemical chaperones increase the cellular activity of N370S $\beta$-glucosidase: a therapeutic strategy for Gaucher disease. Proc. Natl. Acad. Sci. U.S.A. 99, 15428-15433.

57) Ogawa, S., Ashiura, M., Uchida, C., Watanabe, S., Yamazaki, C., Yamagishi, K. and Inokuchi, J.-I. (1996) Synthesis of potent $\beta$-D-glucocerebrosidase inhibitors: $N$-alkyl- $\beta$-valienamines. Bioorg. Med. Chem. Lett. 6, 929-932.

58) Goldin, E., Zheng, W., Motabar, O., Southall, N., Choi, J.H., Marugan, J., Austin, C.P. and Sidransky, E. (2012) High throughput screening for small molecule therapy for Gaucher disease using patient tissue as the source of mutant glucocerebrosidase. PLoS One 7, e29861.

59) Wang, G.N., Twigg, G., Butters, T.D., Zhang, S., Zhang, L., Zhang, L.H. and Ye, X.S. (2012) Synthesis of $N$-substituted $\varepsilon$-hexonolactams as pharmacological chaperones for the treatment of N370S mutant Gaucher disease. Org. Biomol. Chem. 10, 2923-2927.

60) Marugan, J.J., Zheng, W., Motabar, O., Southall, N., Goldin, E., Westbroek, W., Stubblefield, B.K., Sidransky, E., Aungst, R.A., Lea, W.A., Simeonov, A., Leister, W. and Austin, C.P. (2011) Evaluation of quinazoline analogues as glucocerebrosidase inhibitors with chaperone activity. J. Med. Chem. 54, 1033-1058.

61) Trapero, A. and Llebaria, A. (2013) Glucocerebrosidase inhibitors for the treatment of Gaucher disease. Future Med. Chem. 5, 573-590.

62) Patnaik, S., Zheng, W., Choi, J.H., Motabar, O., Southall, N., Westbroek, W., Lea, W.A., Velayati, A., Goldin, E., Sidransky, E., Leister, W. and Marugan, J.J. (2012) Discovery, structure-activity relationship, and biological evaluation of noninhibitory small molecule chaperones of glucocerebrosidase. J. Med. Chem. 55, 5734-5748.

63) Maegawa, G.H., Tropak, M.B., Buttner, J.D., Rigat, B.A., Fuller, M., Pandit, D., Tang, L., Kornhaber, G.J., Hamuro, Y., Clarke, J.T. and Mahuran, D.J. (2009) Identification and characterization of ambroxol as an enzyme enhancement agent for Gaucher disease. J. Biol. Chem. 284, 23502-23516.

64) Zimran, A., Altarescu, G. and Elstein, D. (2013) Pilot study using ambroxol as a pharmacological chaperone in type 1 Gaucher disease. Blood Cells Mol. Dis. 50, 134-137.

65) Tropak, M.B., Reid, S.P., Guiral, M., Withers, S.G. and Mahuran, D. (2004) Pharmacological enhancement of $\beta$-hexosaminidase activity in fibro- 
blasts from adult Tay-Sachs and Sandhoff patients. J. Biol. Chem. 279, 13478-13487.

66) Maegawa, G.H., Tropak, M., Buttner, J., Stockley, T., Kok, F., Clarke, J.T. and Mahuran, D.J. (2007) Pyrimethamine as a potential pharmacological chaperone for late-onset forms of $\mathrm{G}_{\mathrm{M}^{-}}$ gangliosidosis. J. Biol. Chem. 282, 9150-9161.

67) Bateman, K.S., Cherney, M.M., Mahuran, D.J., Tropak, M. and James, M.N. (2011) Crystal structure of $\beta$-hexosaminidase B in complex with pyrimethamine, a potential pharmacological chaperone. J. Med. Chem. 54, 1421-1429.

68) Clarke, J.T., Mahuran, D.J., Sathe, S., Kolodny, E.H., Rigat, B.A., Raiman, J.A. and Tropak, M.B. (2011) An open-label phase I/II clinical trial of pyrimethamine for the treatment of patients affected with chronic $\mathrm{G}_{\mathrm{M} 2}$-gangliosidosis (TaySachs or Sandhoff variants). Mol. Genet. Metab. 102, 6-12.

69) Cortes, C.J., Qin, K., Norstrom, E.M., Green, W.N., Bindokas, V.P. and Mastrianni, J.A. (2013) Early delivery of misfolded PrP from ER to lysosomes by autophagy. Int. J. Cell Biol. 2013, 560421.

70) Lampel, A., Bram, Y., Levy-Sakin, M., Bacharach, E. and Gazit, E. (2013) The effect of chemical chaperones on the assembly and stability of HIV-1 capsid protein. PLoS One 8, e60867.

71) Gelman, M.S. and Kopito, R.R. (2002) Rescuing protein conformation: prospects for pharmacological therapy in cystic fibrosis. J. Clin. Invest. 110 1591-1597.

72) Becq, F., Mettey, Y., Gray, M.A., Galietta, L.J., Dormer, R.L., Merten, M., Metaye, T., Chappe, V., Marvingt-Mounir, C., Zegarra-Moran, O., Tarran, R., Bulteau, L., Derand, R., Pereira, M.M., McPherson, M.A., Rogier, C., Joffre, M., Argent, B.E., Sarrouilhe, D., Kammouni, W., Figarella, C., Verrier, B., Gola, M. and Vierfond, J.M. (1999) Development of substituted benzo[c]quinolizinium compounds as novel activators of the cystic fibrosis chloride channel. J. Biol. Chem. 274, 27415-27425.

73) Stratford, F.L., Pereira, M.M., Becq, F., McPherson, M.A. and Dormer, R.L. (2003) Benzo(c)quinolizinium drugs inhibit degradation of $\triangle$ F508-CFTR cytoplasmic domain. Biochem. Biophys. Res. Commun. 300, 524-530.

74) Pedemonte, N., Lukacs, G.L., Du, K., Caci, E., Zegarra-Moran, O., Galietta, L.J. and Verkman, A.S. (2005) Small-molecule correctors of defective $\Delta$ F508-CFTR cellular processing identified by high-throughput screening. J. Clin. Invest. 115 , 2564-2571.

75) Van Goor, F., Straley, K.S., Cao, D., Gonzalez, J., Hadida, S., Hazlewood, A., Joubran, J., Knapp, T., Makings, L.R., Miller, M., Neuberger, T., Olson, E., Panchenko, V., Rader, J., Singh, A., Stack, J.H., Tung, R., Grootenhuis, P.D. and Negulescu, P. (2006) Rescue of $\Delta$ F508-CFTR trafficking and gating in human cystic fibrosis airway primary cultures by small molecules. Am. J. Physiol. Lung Cell. Mol. Physiol. 290, L1117-
L1130.

76) Wellhauser, L., Kim Chiaw, P., Pasyk, S., Li, C., Ramjeesingh, M. and Bear, C.E. (2009) A smallmolecule modulator interacts directly with $\triangle$ Phe508-CFTR to modify its ATPase activity and conformational stability. Mol. Pharmacol. 75, $1430-1438$

77) Kim Chiaw, P., Wellhauser, L., Huan, L.J., Ramjeesingh, M. and Bear, C.E. (2010) A chemical corrector modifies the channel function of F508del-CFTR. Mol. Pharmacol. 78, 411-418.

78) Van Goor, F., Hadida, S., Grootenhuis, P.D., Burton, B., Stack, J.H., Straley, K.S., Decker, C.J., Miller, M., McCartney, J., Olson, E.R., Wine, J.J., Frizzell, R.A., Ashlock, M. and Negulescu, P.A. (2011) Correction of the F508del-CFTR protein processing defect in vitro by the investigational drug VX-809. Proc. Natl. Acad. Sci. U.S.A. 108, 18843-18848.

79) Pey, A.L., Thorolfsson, M., Teigen, K., Ugarte, M. and Martinez, A. (2004) Thermodynamic characterization of the binding of tetrahydropterins to phenylalanine hydroxylase. J. Am. Chem. Soc. 126, 13670-13678.

80) Pey, A.L., Ying, M., Cremades, N., VelazquezCampoy, A., Scherer, T., Thony, B., Sancho, J. and Martinez, A. (2008) Identification of pharmacological chaperones as potential therapeutic agents to treat phenylketonuria. J. Clin. Invest. 118, 2858-2867.

81) Santos-Sierra, S., Kirchmair, J., Perna, A.M., Reiss, D., Kemter, K., Roschinger, W., Glossmann, H., Gersting, S.W., Muntau, A.C., Wolber, G. and Lagler, F.B. (2012) Novel pharmacological chaperones that correct phenylketonuria in mice. Hum. Mol. Genet. 21, 1877-1887.

82) Hopper, E.D., Pittman, A.M., Fitzgerald, M.C. and Tucker, C.L. (2008) In vivo and in vitro examination of stability of primary hyperoxaluriaassociated human alanine:glyoxylate aminotransferase. J. Biol. Chem. 283, 30493-30502.

83) Porto, C., Ferrara, M.C., Meli, M., Acampora, E., Avolio, V., Rosa, M., Cobucci-Ponzano, B., Colombo, G., Moracci, M., Andria, G. and Parenti, G. (2012) Pharmacological enhancement of $\alpha$-glucosidase by the allosteric chaperone $N$ acetylcysteine. Mol. Ther. 20, 2201-2211.

84) Aymami, J., Barril, X., Rodriguez-Pascau, L. and Martinell, M. (2013) Pharmacological chaperones for enzyme enhancement therapy in genetic diseases. Pharm. Pat. Anal. 2, 109-124.

85) Jorge-Finnigan, A., Brasil, S., Underhaug, J., RuizSala, P., Merinero, B., Banerjee, R., Desviat, L.R., Ugarte, M., Martinez, A. and Perez, B. (2013) Pharmacological chaperones as a potential therapeutic option in methylmalonic aciduria cblB type. Hum. Mol. Genet. 22, 3680-3689.

86) Auluck, P.K., Chan, H.Y., Trojanowski, J.Q., Lee, V.M. and Bonini, N.M. (2002) Chaperone suppression of alpha-synuclein toxicity in a drosophila model for Parkinson's disease. Science 295, 865-868. 
87) Bergeron, L.M., Gomez, L., Whitehead, T.A. and Clark, D.S. (2009) Self-renaturing enzymes: design of an enzyme-chaperone chimera as a new approach to enzyme stabilization. Biotechnol. Bioeng. 102, 1316-1322.

88) Abisambra, J.F., Jinwal, U.K., Jones, J.R., Blair, L.J., Koren, J. 3rd and Dickey, C.A. (2011) Exploiting the diversity of the heat-shock protein family for primary and secondary tauopathy therapeutics. Curr. Neuropharmacol. 9, 623-631.

89) Nakamura, T. and Lipton, S.A. (2009) Cell death: protein misfolding and neurodegenerative diseases. Apoptosis 14, 455-468.

90) Cummings, C.J., Sun, Y., Opal, P., Antalffy, B., Mestril, R., Orr, H.T., Dillmann, W.H. and Zoghbi, H.Y. (2001) Over-expression of inducible HSP70 chaperone suppresses neuropathology and improves motor function in SCA1 mice. Hum. Mol. Genet. 10, 1511-1518.

91) Nagai, Y., Fujikake, N., Popiel, H.A. and Wada, K. (2010) Induction of molecular chaperones as a therapeutic strategy for the polyglutamine diseases. Curr. Pharm. Biotechnol. 11, 188-197.

92) Chaari, A., Hoarau-Vechot, J. and Ladjimi, M. (2013) Applying chaperones to protein-misfolding disorders: Molecular chaperones against alphasynuclein in Parkinson's disease. Int. J. Biol. Macromol. 60C, 196-205.

93) Kirkegaard, T., Roth, A.G., Petersen, N.H., Mahalka, A.K., Olsen, O.D., Moilanen, I., Zylicz, A., Knudsen, J., Sandhoff, K., Arenz, C., Kinnunen, P.K., Nylandsted, J. and Jaattela, M. (2010) Hsp70 stabilizes lysosomes and reverts Niemann-Pick disease-associated lysosomal pathology. Nature 463, 549-553.

94) Petersen, N.H. and Kirkegaard, T. (2010) HSP70 and lysosomal storage disorders: novel therapeutic opportunities. Biochem. Soc. Trans. 38, 14791483.

95) Leandro, J., Simonsen, N., Saraste, J., Leandro, P. and Flatmark, T. (2011) Phenylketonuria as a protein misfolding disease: The mutation pG46S in phenylalanine hydroxylase promotes self-association and fibril formation. Biochim. Biophys. Acta 1812, 106-120.

96) Aerts, J.M., Hollak, C.E., Boot, R.G., Groener, J.E. and Maas, M. (2006) Substrate reduction therapy of glycosphingolipid storage disorders. J. Inherit. Metab. Dis. 29, 449-456.

97) Suzuki, Y., Ichinomiya, S., Kurosawa, M., Ohkubo, M., Watanabe, H., Iwasaki, H., Matsuda, J., Noguchi, Y., Takimoto, K., Itoh, M., Tabe, M., Iida, M., Kubo, T., Ogawa, S., Nanba, E., Higaki, K., Ohno, K. and Brady, R.O. (2007) Chemical chaperone therapy: clinical effect in murine $\mathrm{G}_{\mathrm{M} 1^{-}}$ gangliosidosis. Ann. Neurol. 62, 671-675.

98) Gucev, Z.S., Tasic, V., Jancevska, A., Zafirovski, G., Kremensky, I., Sinigerska, I., Nanba, E., Higaki, K., Gucev, F. and Suzuki, Y. (2008) Novel $\beta$-galactosidase gene mutation p.W273R in a woman with mucopolysaccharidosis type IVB (Morquio B) and lack of response to in vitro chaperone treatment of her skin fibroblasts. Am. J. Med. Genet. 146A, 1736-1740.

99) Lee, W.C., Kang, D., Causevic, E., Herdt, A.R., Eckman, E.A. and Eckman, C.B. (2010) Molecular characterization of mutations that cause globoid cell leukodystrophy and pharmacological rescue using small molecule chemical chaperones. J. Neurosci. 30, 5489-5497.

100) Hossain, M.A., Otomo, T., Saito, S., Ohno, K., Sakuraba, H., Hamada, Y., Ozono, K. and Sakai, N. (2014) Late-onset Krabbe disease is predominant in Japan and its mutant precursor protein undergoes more effective processing than the infantile-onset form. Gene 534, 144-154.

101) Lin, H., Sugimoto, Y., Ohsaki, Y., Ninomiya, H., Oka, A., Taniguchi, M., Ida, H., Eto, Y., Ogawa, S., Matsuzaki, Y., Sawa, M., Inoue, T., Higaki, K., Nanba, E., Ohno, K. and Suzuki, Y. (2004) $N$ octyl- $\beta$-valienamine up-regulates activity of F213I mutant $\beta$-glucosidase in cultured cells: a potential chemical chaperone therapy for Gaucher disease. Biochim. Biophys. Acta 1689, 219-228.

102) Clark, N.E. and Garman, S.C. (2009) The 1.9 a structure of human $\alpha$ - $N$-acetylgalactosaminidase: The molecular basis of Schindler and Kanzaki diseases. J. Mol. Biol. 393, 435-447.

103) Rountree, J.S., Butters, T.D., Wormald, M.R., Boomkamp, S.D., Dwek, R.A., Asano, N., Ikeda, K., Evinson, E.L., Nash, R.J. and Fleet, G.W. (2009) Design, synthesis, and biological evaluation of enantiomeric $\beta$ - $N$-acetylhexosaminidase inhibitors LABNAc and DABNAc as potential agents against Tay-Sachs and Sandhoff disease. ChemMedChem 4, 378-392.

104) Xiao, J., Westbroek, W., Motabar, O., Lea, W.A., Hu, X., Velayati, A., Zheng, W., Southall, N., Gustafson, A.M., Goldin, E., Sidransky, E., Liu, K., Simeonov, A., Tamargo, R.J., Ribes, A., Matalonga, L., Ferrer, M. and Marugan, J.J. (2012) Discovery of a novel noniminosugar acid $\alpha$-glucosidase chaperone series. J. Med. Chem. 55, $7546-7559$

105) Marugan, J.J., Zheng, W., Ferrer, M., Motabar, O., Southall, N., Goldin, E., Westbroek, W. and Sidransky, E. (2010) Discovery, SAR, and biological evaluation of a non-inhibitory chaperone for acid alpha glucosidase. In Probe Reports from the NIH Molecular Libraries Program, Bethesda. Available from: http://www.ncbi.nlm.nih.gov/ pubmed/23905202.

106) Gelsthorpe, M.E., Baumann, N., Millard, E., Gale, S.E., Langmade, S.J., Schaffer, J.E. and Ory, D.S. (2008) Niemann-Pick type C1 I1061T mutant encodes a functional protein that is selected for endoplasmic reticulum-associated degradation due to protein misfolding. J. Biol. Chem. 283, 8229-8236.

107) Ohgane, K., Karaki, F., Dodo, K. and Hashimoto, Y. (2013) Discovery of oxysterol-derived pharmacological chaperones for NPC1: Implication for the existence of second sterol-binding site. Chem. Biol. 20, 391-402. 
108) Venugopal, B., Mesires, N.T., Kennedy, J.C., Curcio-Morelli, C., Laplante, J.M., Dice, J.F. and Slaugenhaupt, S.A. (2009) Chaperone-mediated autophagy is defective in mucolipidosis type IV. J. Cell. Physiol. 219, 344-353.

109) Walus, M., Kida, E. and Golabek, A.A. (2010) Functional consequences and rescue potential of pathogenic missense mutations in tripeptidyl peptidase I. Hum. Mutat. 31, 710-721.

110) Rusyn, E., Mousallem, T., Persaud-Sawin, D.A., Miller, S. and Boustany, R.M. (2008) CLN3p impacts galactosylceramide transport, raft morphology, and lipid content. Pediatr. Res. 63, 625631.

111) Ficko-Blean, E., Stubbs, K.A., Nemirovsky, O., Vocadlo, D.J. and Boraston, A.B. (2008) Structural and mechanistic insight into the basis of mucopolysaccharidosis IIIB. Proc. Natl. Acad. Sci. U.S.A. 105, 6560-6565.

112) Feldhammer, M., Durand, S. and Pshezhetsky, A.V. (2009) Protein misfolding as an underlying molecular defect in mucopolysaccharidosis III type C. PLoS One 4, e7434.

113) de Ruijter, J., Valstar, M.J. and Wijburg, F.A. (2011) Mucopolysaccharidosis type III (Sanfilippo syndrome): emerging treatment strategies. Curr. Pharm. Biotechnol. 12, 923-930.

114) Takahashi, N., Morita, M. and Imanaka, T. (2007) [Adrenoleukodystrophy: structure and function of ALDP, and intracellular behavior of mutant ALDP with naturally occurring missense mutations]. Yakugaku Zasshi (J. Pharmaceut. Soc. Jpn.) 127, 163-172 (in Japanese).

115) Zhang, R., Chen, L., Jiralerspong, S., Snowden, A., Steinberg, S. and Braverman, N. (2010) Recovery of PEX1-Gly843Asp peroxisome dysfunction by small-molecule compounds. Proc. Natl. Acad. Sci. U.S.A. 107, 5569-5574.

116) Ilieva, E.V., Kichev, A., Naudi, A., Ferrer, I., Pamplona, R. and Portero-Otin, M. (2011) Mitochondrial dysfunction and oxidative and endoplasmic reticulum stress in argyrophilic grain disease. J. Neuropathol. Exp. Neurol. 70, 253-263.

117) Calvo, A.C., Scherer, T., Pey, A.L., Ying, M., Winge, I., McKinney, J., Haavik, J., Thony, B. and Martinez, A. (2010) Effect of pharmacological chaperones on brain tyrosine hydroxylase and tryptophan hydroxylase 2. J. Neurochem. 114, 853-863.

118) Pey, A.L. (2013) Protein homeostasis disorders of key enzymes of amino acids metabolism: mutation-induced protein kinetic destabilization and new therapeutic strategies. Amino Acids 45, $1331-1341$.

119) McCorvie, T.J., Gleason, T.J., Fridovich-Keil, J.L. and Timson, D.J. (2013) Misfolding of galactose 1phosphate uridylyltransferase can result in type I galactosemia. Biochim. Biophys. Acta 1832 1279-1293.

120) Rymen, D., Peanne, R., Millon, M.B., Race, V., Sturiale, L., Garozzo, D., Mills, P., Clayton, P., Asteggiano, C.G., Quelhas, D., Cansu, A.,
Martins, E., Nassogne, M.C., Goncalves-Rocha, M., Topaloglu, H., Jaeken, J., Foulquier, F. and Matthijs, G. (2013) MAN1B1 deficiency: An unexpected CDG-II. PLoS Genet. 9, e1003989.

121) Gibbs, S.J. and Braun, J.E. (2008) Emerging roles of $\mathrm{J}$ proteins in neurodegenerative disorders. Neurobiol. Dis. 32, 196-199.

122) Anderson, P.C. and Daggett, V. (2008) Molecular basis for the structural instability of human DJ-1 induced by the L166P mutation associated with Parkinson's disease. Biochemistry 47, 9380-9393.

123) Vogiatzi, T., Xilouri, M., Vekrellis, K. and Stefanis, L. (2008) Wild type $\alpha$-synuclein is degraded by chaperone-mediated autophagy and macroautophagy in neuronal cells. J. Biol. Chem. 283, 23542-23556.

124) Altar, C.A., Vawter, M.P. and Ginsberg, S.D. (2009) Target identification for CNS diseases by transcriptional profiling. Neuropsychopharmacology 34, 18-54.

125) Dimant, H., Ebrahimi-Fakhari, D. and McLean, P.J. (2012) Molecular chaperones and co-chaperones in Parkinson disease. Neuroscientist 18, 589601.

126) Yang, D.S., Yip, C.M., Huang, T.H., Chakrabartty, A. and Fraser, P.E. (1999) Manipulating the amyloid- $\beta$ aggregation pathway with chemical chaperones. J. Biol. Chem. 274, 32970-32974.

127) Wyatt, A.R., Yerbury, J.J., Poon, S. and Wilson, M.R. (2009) Therapeutic targets in extracellular protein deposition diseases. Curr. Med. Chem. 16, 2855-2866.

128) Bocharova, N., Chave-Cox, R., Sokolov, S., Knorre, D. and Severin, F. (2009) Protein aggregation and neurodegeneration: clues from a yeast model of Huntington's disease. Biochemistry (Mosc.) 74, 231-234.

129) Sakurai, H., Sawai, M., Ishikawa, Y., Ota, A. and Kawahara, E. (2014) Heat shock transcription factor HSF1 regulates the expression of the Huntingtin-interacting protein HYPK. Biochim. Biophys. Acta 1840, 1181-1187.

130) Pandya, R.S., Zhu, H., Li, W., Bowser, R., Friedlander, R.M. and Wang, X. (2013) Therapeutic neuroprotective agents for amyotrophic lateral sclerosis. Cell. Mol. Life Sci. 70, 4729-4745.

131) Tatzelt, J., Prusiner, S.B. and Welch, W.J. (1996) Chemical chaperones interfere with the formation of scrapie prion protein. EMBO J. 15, 6363-6373.

132) Nicoll, A.J., Trevitt, C.R., Tattum, M.H., Risse, E., Quarterman, E., Ibarra, A.A., Wright, C., Jackson, G.S., Sessions, R.B., Farrow, M., Waltho, J.P., Clarke, A.R. and Collinge, J. (2010) Pharmacological chaperone for the structured domain of human prion protein. Proc. Natl. Acad. Sci. U.S.A. 107, 17610-17615.

133) Hellerschmied, D. and Clausen, T. (2014) Myosin chaperones. Curr. Opin. Struct. Biol. 25, 9-15.

134) Sampson, H.M., Robert, R., Liao, J., Matthes, E., Carlile, G.W., Hanrahan, J.W. and Thomas, D.Y. (2011) Identification of a NBD1-binding pharmacological chaperone that corrects the trafficking 
defect of F508del-CFTR. Chem. Biol. 18, 231-242.

135) Benitez, J.J., Keller, A.M., Ochieng, P., Yatsunyk, L.A., Huffman, D.L., Rosenzweig, A.C. and Chen, P. (2008) Probing transient copper chaperoneWilson disease protein interactions at the singlemolecule level with nanovesicle trapping. J. Am. Chem. Soc. 130, 2446-2447.

136) Gonzales, E., Grosse, B., Cassio, D., Davit-Spraul, A., Fabre, M. and Jacquemin, E. (2012) Successful mutation-specific chaperone therapy with 4-phenylbutyrate in a child with progressive familial intrahepatic cholestasis type 2. J. Hepatol. 57, 695-698.

137) Misawa, T., Hayashi, H., Sugiyama, Y. and Hashimoto, Y. (2012) Discovery and structural development of small molecules that enhance transport activity of bile salt export pump mutant associated with progressive familial intrahepatic cholestasis type 2. Bioorg. Med. Chem. 20, 29402949.

138) Morello, J.P., Salahpour, A., Laperriere, A., Bernier, V., Arthus, M.F., Lonergan, M., Petaja-Repo, U., Angers, S., Morin, D., Bichet, D.G. and Bouvier, M. (2000) Pharmacological chaperones rescue cell-surface expression and function of misfolded V2 vasopressin receptor mutants. J. Clin. Invest. 105, 887-895.

139) Bernier, V., Morello, J.P., Zarruk, A., Debrand, N., Salahpour, A., Lonergan, M., Arthus, M.F., Laperriere, A., Brouard, R., Bouvier, M. and Bichet, D.G. (2006) Pharmacologic chaperones as a potential treatment for X-linked nephrogenic diabetes insipidus. J. Am. Soc. Nephrol. 17, 232243.

140) Bonapace, G., Waheed, A., Shah, G.N. and Sly, W.S. (2004) Chemical chaperones protect from effects of apoptosis-inducing mutation in carbonic anhydrase IV identified in retinitis pigmentosa 17. Proc. Natl. Acad. Sci. U.S.A. 101, 12300-12305.

141) Noorwez, S.M., Sama, R.R. and Kaushal, S. (2009) Calnexin improves the folding efficiency of mutant rhodopsin in the presence of pharmacological chaperone 11-cis retinal. J. Biol. Chem. 284, 33333-33342.

142) Ohgane, K., Dodo, K. and Hashimoto, Y. (2011) [Structural development study of a novel pharmacological chaperone for folding-defective rhodopsin mutants responsible for retinitis pigmentosa]. Yakugaku Zasshi (J. Pharmaceut. Soc. Jpn.) 131, 325-334 (in Japanese).

143) Lee, D., Santos, D., Al-Rawi, H., McNeill, A.M. and Rugg, E.L. (2008) The chemical chaperone trimethylamine $\mathrm{N}$-oxide ameliorates the effects of mutant keratins in cultured cells. Br. J. Dermatol. 159, 252-255.

144) Chamcheu, J.C., Navsaria, H., Pihl-Lundin, I., Liovic, M., Vahlquist, A. and Torma, H. (2011) Chemical chaperones protect epidermolysis bullosa simplex keratinocytes from heat stress-induced keratin aggregation: involvement of heat shock proteins and MAP kinases. J. Invest. Dermatol. 131, 1684-1691.
145) Canals, M., Lopez-Gimenez, J.F. and Milligan, G. (2009) Cell surface delivery and structural reorganization by pharmacological chaperones of an oligomerization-defective $\alpha(1 \mathrm{~b})$-adrenoceptor mutant demonstrates membrane targeting of GPCR oligomers. Biochem. J. 417, 161-172.

146) Nakamura, M., Yasuda, D., Hirota, N. and Shimizu, T. (2010) Specific ligands as pharmacological chaperones: the transport of misfolded G-protein coupled receptors to the cell surface. IUBMB Life 62, 453-459.

147) Conn, P.M. and Janovick, J.A. (2011) Pharmacoperone identification for therapeutic rescue of misfolded mutant proteins. Front. Endocrinol. (Lausanne) 2, doi:10.3389/fendo.2011.00006.

148) Maya-Nunez, G., Ulloa-Aguirre, A., Janovick, J.A. and Conn, P.M. (2012) Pharmacological chaperones correct misfolded GPCRs and rescue function: protein trafficking as a therapeutic target. Subcell. Biochem. 63, 263-289.

149) Smithson, D.C., Janovick, J.A. and Conn, P.M. (2013) Therapeutic rescue of misfolded/ mistrafficked mutants: automation-friendly highthroughput assays for identification of pharmacoperone drugs of GPCRs. Methods Enzymol. 521, $3-16$.

150) da-Silva, W.S., Ribich, S., Drigo, R.A., Castillo, M., Patti, M.E. and Bianco, A.C. (2011) The chemical chaperones tauroursodeoxycholic and 4-phenylbutyric acid accelerate thyroid hormone activation and energy expenditure. FEBS Lett. 585, 539-544.

151) Rene, P., Le Gouill, C., Pogozheva, I.D., Lee, G., Mosberg, H.I., Farooqi, I.S., Valenzano, K.J. and Bouvier, M. (2010) Pharmacological chaperones restore function to MC4R mutants responsible for severe early-onset obesity. J. Pharmacol. Exp. Ther. 335, 520-532.

152) Sanbe, A., Daicho, T., Mizutani, R., Endo, T., Miyauchi, N., Yamauchi, J., Tanonaka, K., Glabe, C. and Tanoue, A. (2009) Protective effect of geranylgeranylacetone via enhancement of HSPB8 induction in desmin-related cardiomyopathy. PLoS One 4, e5351.

153) Taylor, M., Banerjee, T., Navarro-Garcia, F., Huerta, J., Massey, S., Burlingame, M., Pande, A.H., Tatulian, S.A. and Teter, K. (2011) A therapeutic chemical chaperone inhibits cholera intoxication and unfolding/translocation of the cholera toxin A1 subunit. PLoS One 6, e18825.

154) Simms-Waldrip, T., Rodriguez-Gonzalez, A., Lin, T., Ikeda, A.K., Fu, C. and Sakamoto, K.M. (2008) The aggresome pathway as a target for therapy in hematologic malignancies. Mol. Genet. Metab. 94, 283-286.

155) Zhang, C. and Cuervo, A.M. (2008) Restoration of chaperone-mediated autophagy in aging liver improves cellular maintenance and hepatic function. Nat. Med. 14, 959-965. 


\section{Profile}

Yoshiyuki Suzuki completed his doctorate in medical science with the clinical analysis of movements and posture in cerebral palsy patients at the University of Tokyo in 1966. After his clinical studies of neurological diseases, he started biochemical and molecular analyses of lysosomal diseases at various research institutions in the United States and Japan. His major scientific achievements include discovery of the deficient enzyme (galactosylceramidase) in Krabbe disease (1970-71) at University of Pennsylvania; pathogenesis of galactosialidosis (1977-83) at The University of Tokyo; molecular pathology of $\beta$-galactosidase deficiency disorders, particularly $\mathrm{G}_{\mathrm{M} 1}$-gangliosidosis (198592) at National Center of Neurology and Psychiatry, and The Tokyo Metropolitan Institute of Medical Science (Rinshoken); and then proposal of the concept of chaperone

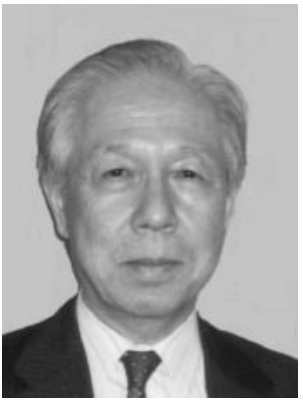
therapy for lysosomal diseases (1995-present) at Rinshoken, and International University of Health and Welfare. This concept has opened a new scope for molecular therapy of lysosomal diseases, and is expanding to a large number of other genetic and non-genetic diseases. He was awarded Weil Award (American Association of Neuropathologists), Mitsukoshi Medical Foundation Prize, Japan IBM Prize (Japanese Society for Inborn Errors of Metabolism), Frank Ford Memorial Award (International Child Neurology Association) and other prestigious awards. He was Visiting Professor at University of Siena (Italy), Visiting Professor at Peking University First Teaching Hospital (China), and Honorary Professor at Almaty State Medical Institute of Postgraduate Education (Kazakhstan). Additionally his international activities include International Child Neurology Association (President, Secretary), and World Health Organization (NGO for Prevention and Treatment of Neurological Diseases, International Task Force for Developmental Disabilities in Children, and Chair of the Child Neurology Working Group). He is currently Special Visiting Scientist at Tokyo Metropolitan Institute of Medical Science. 